\title{
Premio Coloma Barbé a la mejor comunicación oral y al mejor póster
}

El Premio Coloma Barbé, concedido por primera vez en el marco de los Encuentros de Ciencias de la Salud, se concede a aquella comunicación que haya contribuido a desarrollar los valores docentes, científicos y humanos que caracterizaban la bondad de la persona que durante años fue impulsora y presidenta de estos Encuentros.

El galardón tiene un reconocimiento testimonial, con la entrega de un obsequio, la publicación del contenido de la comunicación en un artículo en la revista FEM y la inscripción gratuita al 8. Encuentro de Profesorado de Ciencias de la Salud.

En cada una de las sesiones expositivas de las co- municaciones orales y pósteres, los moderadores evalúan las comunicaciones presentadas en función de la calidad del resumen, el formato de la comunicación y el contenido innovador.

Finalmente, habiendo procedido a la votación de las candidaturas finalistas de cada una de las sesiones, el jurado decidirá otorgar el I Premio Coloma Barbé a la mejor comunicación en formato oral y en formato póster a cada presentador de dichas comunicaciones en el 7. ${ }^{\circ}$ Encuentro de Profesorado de Ciencias de la Salud, celebrado en la Facultad de Farmacia, los días 30 y 31 de enero y 1 de febrero de 2013. 